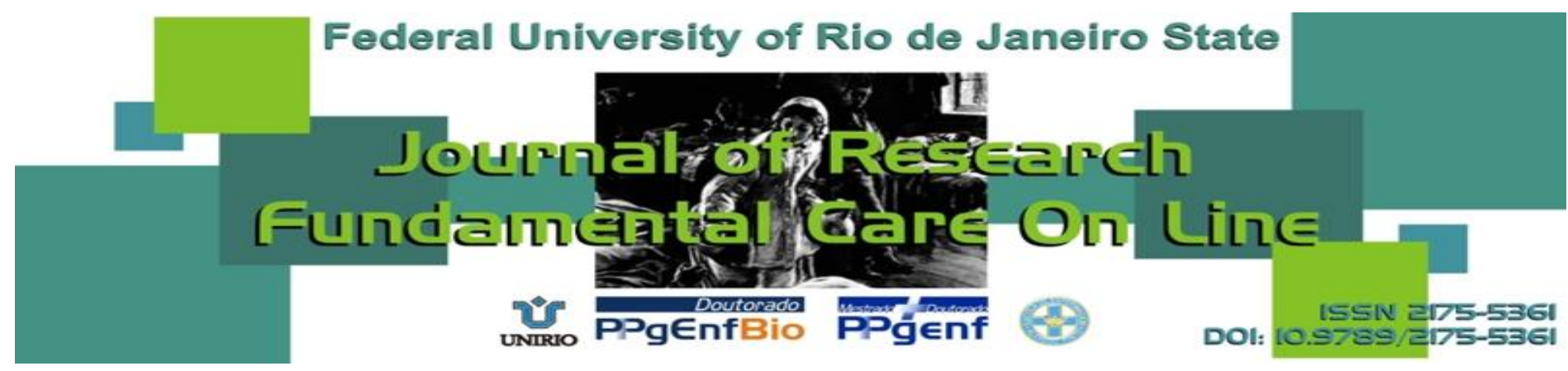

\title{
INTEGRATIVE REVIEW OF THE LITERATURE
}

Scientific production on quality of life in patients with renal undergoing hemodialysis

Produção científica sobre qualidade de vida de pacientes com insuficiência renal submetidos à hemodiálise

Producción científica acerca de la calidad de vida en pacientes con insuficiencia renal sometidos a hemodiálisis

Odson Davi Costa Vieira ${ }^{1}$, Samuel Ricardo Batista Moura², João Pedro Pinheiro ${ }^{3}$, Andrea de Castro Silva ${ }^{4}$, Arthur Flavio Linard Paes Landim ${ }^{5}$, Maria do Carmo de Carvalho e Martins ${ }^{6}$

\section{ABSTRACT}

Objective: To analyze the scientific production on quality of life of patients with renal failure undergoing hemodialysis. Method: This is an integrative literature review conducted on the banks of LILACS and MEDLINE databases. Were selected studies published between 2011 to 2013 and analyzed 24 articles. Results: The results indicated that the quality of life of hemodialysis patients is related to factors, physical, psychosocial, mental, social and presence and support of family. Conclusion: The development of studies involving the quality of life of individuals may assist healthcare professionals in the instrumentalization of a healthcare practice that really contemplate the multidimensionality of care to patients with renal failure undergoing hemodialysis. Descriptors: Renal failure, Hemodialysis, Quality of life, Treatment.

\section{RESUMO}

Objetivo: Analisar a produção científica sobre a qualidade de vida de pacientes com insuficiência renal, submetidos à hemodiálise. Método: Trata-se de uma revisão integrativa da literatura realizada nos bancos de dados LILACS e MEDLINE. Foram selecionados estudos publicados no período de 2011 a 2013 e analisados 24 artigos. Resultado: Os resultados indicaram que a qualidade de vida dos pacientes submetidos à hemodiálise está relacionada a fatores, físicos, psicossociais, mentais, sociais e a presença e apoio da família. Conclusão: 0 desenvolvimento de estudos que envolvem a qualidade de vida do indivíduo pode auxiliar os profissionais da saúde na instrumentalização de uma prática assistencial que realmente contemple a multidimensionalidade do cuidado a pacientes com insuficiência renal submetidos à hemodiálise. Descritores: Insuficiência renal, Hemodiálise, Qualidade de vida, Tratamento.

\section{RESUMEN}

Objetivo: Analizar la producción científica sobre la calidad de vida de los pacientes con insuficiencia renal sometidos a hemodiálisis. Método: Se trata de una revisión integradora de la literatura realizada en los bancos de datos LILACS y MEDLINE. Fueron seleccionados estudios publicados entre los años 2011 a 2013 y analizados 24 artículos. Resultados: Los resultados indicaron que la calidad de vida de los pacientes en hemodiálisis se relaciona con factores, físicos, psicosociales, mentales, sociales y la presencia y apoyo da familia. Conclusión: El desarrollo estudios que envuelven la calidad de vida del individuo puede ayudar los profesionales de la salud en la instrumentalización de una práctica asistencial que realmente contemple la multidimensionalidad de la atención a los pacientes con insuficiencia renal sometidos a hemodiálisis. Descriptores: Insuficiencia renal, Hemodiálisis, Calidad de vida, Tratamiento.

\footnotetext{
${ }^{1}$ Graduando do Curso de Medicina do Centro Universitário UNINOVAFAPI. Email: davi_cv@hotmail.com

${ }^{2}$ Graduando do Curso de Medicina do Centro Universitário UNINOVAFAPI. Email: samuel_ricardo69@hotmail.com

${ }^{3}$ Graduando do Curso de Medicina do Centro Universitário UNINOVAFAPI. Email: jpedropinheiro@hotmail.com

${ }^{4}$ Graduando do Curso de Medicina do Centro Universitário UNINOVAFAPI. Email: andreeacastro@yahoo.com.br

${ }^{5}$ Graduando do Curso de Medicina do Centro Universitário UNINOVAFAPI.Email: arthurlinardpaeslandim@yahoo.com.br

6 Doutora em Ciências Biológicas pela UFPE. Professora do Programa de Mestrado Profissional em Saúde da Família do Centro

Universitário UNINOVAFAPI. mmartins@uninovafapi.edu.br
} 
Vieira ODC, Moura SRB, Pinheiro JP et al.

\section{INTRODUCTION}

Renal failure is a condition in which the kidneys lose their ability to perform its basic functions. Kidney failure can be acute (ARF) when occurs sudden and rapid loss of kidney function or chronic (CRF), when this loss is slowly, progressive and irreversible. The kidneys are responsible for regulating the balance of water and often constitute the major route of elimination of water from the body. When the amount of water consumed is small or the water lost increases, as during physical exercise, kidneys conserve water by producing a lower volume of urine, which is hypertonic with respect to plasma. When water intake is large, a high volume of hyposmotic urine is produced. In a normal individual, urine osmolality can vary from 50 to 1,200 mOsm / kg $\mathrm{H} 2 \mathrm{O}$ approximately corresponding urine volume and may vary ,approximately, $18 \mathrm{~L} /$ day to as little as 0.5 liters / day. ${ }^{1}$

ARF is characterized by a sudden decrease in renal function, resulting in the inability of the kidneys to perform their basic functions of excretion and maintenance of hydroelectrolytic homeostasis. Despite advances in the understanding of the pathophysiological ARF, still has a high degree of mortality. ${ }^{2}$

The CRF is a complex syndrome caused by the loss of renal excretory capacity, usually installed in a slow and progressive manner. As a result there will be a rise in plasma or serum concentrations of all catabolites derived primarily from protein metabolism, characterized by increased urea and creatinine. Among the causes of CRF are: primary renal diseases, systemic diseases, hereditary diseases and congenital malformations. Treatment should be focused on the restoration of low-protein diet, use of antihypertensive drugs, treatment of acidosis,
Scientific production on quality of life in patients... hyperkalemia, anemia, renal osteodystrophy, dialysis or transplantation. ${ }^{3}$

The dialytic methods are currently available peritoneal dialysis, hemodialysis, hemodiafiltration and hemofiltration. These processes can be arteriovenous and venovenosos, and run intermittently or continuously. Hemodialysis is the most widely used extracorporeal method for specialized treatment of medical and nursing staff. Pathway is required for circulatory access can be arteriovenous and venovenous. The most used venovenous access in our environment is usually achieved by staining of double-lumen catheter in the internal jugular or subclavian vein. The blood flow of the patient by blood pump is controlled to obtain a constant value of $250-350 \mathrm{ml} / \mathrm{min}$. The movement of solutes is bidirectional, there solute moving from the blood to the dialysate, as urea and potassium and other solutes, such as calcium and bicarbonate dialysate that moves into the blood. Most of the solute transport occurs by diffusion, and removal of fluid by ultrafiltration due to the hydraulic pressure gradient. It appears, therefore, that hemodialysis is much more efficient for correction of uremia and withdrawal volume than peritoneal dialysis. ${ }^{4}$

Therefore, through the dialysis are removed from the blood substances which, when in excess, bring harm to the body, such as urea, potassium, sodium and water. The dialysis is taken in a machine, through a dialyzer (or capillary filter). The dialyzer is a set of pipes called "lines", through which the blood passes an artificial extracorporeal filtration process. During filtration, blood is withdrawn from the body and returns to it through access lines of the veins and arteries simulate circuits. The dialyzer is reusable and after each hemodialysis session is performed chemical sterilization of this material. ${ }^{5}$

Formerly hemodialysis had intended just to avoid death by hypervolemia or hyperkalemia. Nowadays, in addition to reversing the uremic 
Vieira ODC, Moura SRB, Pinheiro JP et al.

symptoms, this treatment seeks, over the long term, reduced complications, reduced risk of mortality, improving quality of life and social reintegration of the individual.

The CRF patients on hemodialysis have many physical, nutritional and social limitations and suffer a painful and distressing treatment of major risk during hemodialysis sessions, impacting their quality of life.

In this sense this study aims to analyze the scientific literature on the quality of life of patients with renal failure who are undergoing hemodialysis.

\section{METHODOLOGY}

This is a study of integrative review of literature operationalized from the following steps: identification of the topic and selection of research question; establishment of criteria for inclusion and exclusion; identification of pre-screened and selected studies, categorization of the selected studies; analysis and interpretation of results, presentation of review / synthesis of knowledge.

The question that guided this study was: which is the scientific production on the quality of life of patients with renal failure undergoing hemodialysis?

To achieve the proposed objectives, a survey was conducted in the electronic databases: Latin American and Caribbean Literature on Health Sciences (LILACS) and International Literature on Health Sciences (MEDLINE). We chose these fonts because they are known databases, the wide distribution and easy access. Was used as descriptors for the survey of scientific production: renal failure, hemodialysis, quality of life and treatment.

For the selection of the sample was established the following inclusion criteria: online J. res.: fundam. care. online 2013.dec. 5(6): 338-347
Scientific production on quality of life in patients... articles available fully that addressed the issues hemodialysis, renal failure and quality of life, and articles published in Portuguese, English and Spanish in the period 2011-2013. Exclusion criteria was chosen: research in pediatric services; studies in editorial formats, case studies, epidemiological studies, dissertations, theses and comments.

In the first search with descriptors 85 articles in LILACS and 1,147 were found in MEDLINE. After applying the inclusion criteria and full reading of the studies were selected for this study sample 24 articles.

Frame1 - Presentation of search steps, inclusion criteria and selection of the study sample

\begin{tabular}{|c|c|c|c|}
\hline Databases & $\begin{array}{l}\text { Search with } \\
\text { descriptors }\end{array}$ & $\begin{array}{l}\text { Application of inclusion } \\
\text { criteria }\end{array}$ & $\begin{array}{l}\text { Selecting sample after read } \\
\text { it in full }\end{array}$ \\
\hline LILACS & 85 articles & 66 articles & 4 articles \\
\hline MEDLINE & 1147 articles & 340 articles & 20 articles \\
\hline
\end{tabular}

\section{RESULTS AND DISCUSSION}

In the integrative review, were analyzed 24 articles that met the inclusion criteria previously established. Below in Frame 2, an overview of the reviewed articles will present itself.

Among the articles included in the integrative review, in relation to the year of publication 16 articles were published in 2011 and eight in 2012, no article was published in 2013. Regarding the type of journal in which the articles review were published included in the, three were published in journals of general nursing, three journals in perioperative nursing, both in medical journals and six were published in journals of other health areas. Of the 24 articles analyzed, 10 were published in Portuguese and 13 in English and 01 in Spanish. 
Vieira ODC, Moura SRB, Pinheiro JP et al.

Frame 2: Distribution of studies according to the title of articles, authors, journal, year of publication and Language (2011-2013)

\begin{tabular}{|c|c|c|c|c|c|}
\hline $\mathbb{N}$ & ТІТИ & & & & \\
\hline 01 & $\begin{array}{l}\text { Quality of life in patients with } \\
\text { chronickidney disease }\end{array}$ & $\begin{array}{l}\text { AUIORES } \\
\text { Cruz MC, AndradeC, Urrutia } \\
\text { M, Draibe S, Nogueira- }\end{array}$ & \begin{tabular}{|l} 
PERIODICO \\
Clinics
\end{tabular} & $\begin{array}{l}\text { ANO } \\
2011\end{array}$ & \begin{tabular}{|l} 
IDIOMA \\
English
\end{tabular} \\
\hline 02 & $\begin{array}{l}\text { Depression andquality oflife of } \\
\text { hemodialysis patients living in a } \\
\text { poor region of Brazil }\end{array}$ & $\begin{array}{l}\text { Martins LA, Sesso RCC. } \\
\text { Santos PR. }\end{array}$ & \begin{tabular}{|l} 
Revista \\
Brasileira de \\
Psiquiatria
\end{tabular} & 2011 & English \\
\hline 03 & $\begin{array}{l}\text { Predialysis therapeutic care and } \\
\text { health-related quality of life at } \\
\text { dialysis on set (The } \\
\text { pharmacoepidemiologic AVENIR } \\
\text { study) }\end{array}$ & $\begin{array}{l}\text { Boinis, FrimatLuc, Kessler } \\
\text { M, Briançon S, Thilly N. }\end{array}$ & \begin{tabular}{|l|} 
Health and \\
Quality of Life \\
Outcomes
\end{tabular} & 2011 & English \\
\hline 04 & $\begin{array}{l}\text { Hemodialysis in a Satellite Unit: } \\
\text { Clinical Performance Target } \\
\text { Attainment and Health-Related } \\
\text { Quality of Life }\end{array}$ & $\begin{array}{l}\text { Diamant MJ, Young A, Gallo } \\
\text { K, Xi W, Suri RS, Garg } \\
\text { AX, MoistLM. }\end{array}$ & $\begin{array}{l}\text { Journal of the } \\
\text { American } \\
\text { Society.of } \\
\text { Nephrology }\end{array}$ & 2011 & English \\
\hline 05 & $\begin{array}{l}\text { Fatores associados com a } \\
\text { qualidade de vida relacionada a } \\
\text { saude de idosos em hemodialise }\end{array}$ & $\begin{array}{l}\text { Braga SFM, PeixotoSV, } \\
\text { Gomes IC,Acurcio FA, } \\
\text { Andrade ElGl, Cherchiglia } \\
\text { ML. }\end{array}$ & $\begin{array}{l}\text { Revista de } \\
\text { Saude Püblica }\end{array}$ & 2011 & \begin{tabular}{|l} 
Portuguese \\
\end{tabular} \\
\hline 06 & $\begin{array}{l}\text { The confluence offumaman } \\
\text { genomis, ervironment, and } \\
\text { determinants of health-related } \\
\text { quality of life among African } \\
\text { American hemodialysis patients }\end{array}$ & Thomas CJ. & $\begin{array}{l}\text { SocWork } \\
\text { PublicHealth }\end{array}$ & 2011 & English \\
\hline 07 & $\begin{array}{l}\text { Afisioterapia podeinfluendar na } \\
\text { qualidade de vida deindividuos } \\
\text { em hemodiálise }\end{array}$ & $\begin{array}{l}\text { Padulla SAT, MattaMV, } \\
\text { MelattoT, Miranda RCV, } \\
\text { Camargo MR. }\end{array}$ & \begin{tabular}{|l|} 
Ciéncia \\
cuidado Saúde
\end{tabular} & 2011 & \begin{tabular}{|l} 
Portuguese \\
\end{tabular} \\
\hline 08 & $\begin{array}{l}\text { A qualidadede vida dos padentes } \\
\text { renais crönicos em hemodialise na } \\
\text { regiao de Marlia, Sao Paulo }\end{array}$ & Ferreira RC, siva Filho CR. & \begin{tabular}{|l|}
$\begin{array}{l}\text { Jornal } \\
\text { Brasileiro de } \\
\text { Nefrologia }\end{array}$ \\
\end{tabular} & 2011 & \begin{tabular}{|l} 
Portuguese \\
\end{tabular} \\
\hline 09 & $\begin{array}{l}\text { Perceppóes e mudanças na } \\
\text { qualidade de vida de pacientes } \\
\text { submetidos a hemodialise }\end{array}$ & $\begin{array}{l}\text { Silva AS, Slveira RS, } \\
\text { Fernandes GFM, Lunardi VL, } \\
\text { Backes VMS. }\end{array}$ & \begin{tabular}{|l|} 
Revista \\
Brasileira de \\
Enfermagem
\end{tabular} & 2011 & \begin{tabular}{|l} 
Portuguese \\
\end{tabular} \\
\hline 10 & $\begin{array}{l}\text { Avaliaçáo da qualidade de vida } \\
\text { em idosos submetidos ao } \\
\text { tratamento hemodialitico }\end{array}$ & $\begin{array}{l}\text { Takemoto AY, OkuboP, } \\
\text { Bedendo J, Carreira L. }\end{array}$ & \begin{tabular}{|l|} 
Revista \\
Gaúcha de \\
Enfermagem
\end{tabular} & 2011 & \begin{tabular}{|l} 
Portuguese \\
\end{tabular} \\
\hline 11 & $\begin{array}{l}\text { Comparaçáo da qualidade devida } \\
\text { entre pacientes em hemodialise } \\
\text { aguardando e nao aguardando } \\
\text { transplanterenal lem uma regiäo } \\
\text { pobre do Brasil }\end{array}$ & Santos PR. & $\begin{array}{l}\text { Jornal } \\
\text { Brasileiro de } \\
\text { Nefrologia }\end{array}$ & 2011 & \begin{tabular}{|l} 
Portuguese \\
\end{tabular} \\
\hline 12 & $\begin{array}{l}\text { Analise do estilo de vida de renais } \\
\text { crônicos em hemodialise }\end{array}$ & $\begin{array}{l}\text { Kirchner RM, MachadoRF, } \\
\text { Löbler L, Stumm EMF. }\end{array}$ & $\begin{array}{l}\begin{array}{l}\text { O mundo da } \\
\text { saúde }\end{array} \\
\end{array}$ & 2011 & Portuguese \\
\hline 13 & $\begin{array}{l}\text { Factores Psicosociales } \\
\text { Relacionados conla Calidad de } \\
\text { Vida em Saluden Pacientes } \\
\text { Hemodializados }\end{array}$ & $\begin{array}{l}\text { Urzua A, Pavlovk, } \\
\text { Cortes R, Pino V. }\end{array}$ & Terpsicol & 2011 & Spanish \\
\hline 14 & $\begin{array}{l}\text { Nutritionalstatus evaluatede2011 } \\
\text { by multi-frequency bioimpedance } \\
\text { is not assodiated with quality of } \\
\text { life or depressiviv symmtoms in } \\
\text { hemodialysis patients. }\end{array}$ & $\begin{array}{l}\text { Barros A, Costa BE, Poli- } \\
\text { de-Figueiredo } \\
\text { CE, Antonello IC, d'Avila } \\
\text { D. }\end{array}$ & Ther Apher vial & 2012 & English \\
\hline 15 & $\begin{array}{l}\text { Vitamin D deficency, self- } \\
\text { reported physical activity and } \\
\text { health-related quality of life: the } \\
\text { Comprehensive Dialysis Study }\end{array}$ & $\begin{array}{l}\text { AnandS, Kaysen } \\
\text { GA, Chertow } \\
\text { GM, Johansen KL, Grimes } \\
\text { B, Dalrymple LS, Kurella } \\
\text { TM. }\end{array}$ & $\begin{array}{l}\text { Nephrology } \\
\text { Dialysis } \\
\text { Transplantation }\end{array}$ & 2012 & English \\
\hline 16 & $\begin{array}{l}\text { Qualidade de vida de pacientes } \\
\text { submetidos a hemodialise }\end{array}$ & $\begin{array}{l}\text { Farias PFMC, Ramos PV, } \\
\text { Lira CBLA }\end{array}$ & $\begin{array}{l}\text { Revista de } \\
\text { Enfermagem da } \\
\text { UERJ }\end{array}$ & 2012 & Portuguese \\
\hline 17 & $\begin{array}{l}\text { Distance between residence and } \\
\text { the dialysis unit does not impact } \\
\text { selff-perceevived outcomesin } \\
\text { hemodialysis patients }\end{array}$ & $\begin{array}{l}\text { SantospR, Arcanjo } \\
\text { FPN. } 20\end{array}$ & $\begin{array}{l}\text { BMCResearchN } \\
\text { otes }\end{array}$ & 2012 & English \\
\hline 18 & $\begin{array}{l}\text { Efetividade do exerdico fisico na } \\
\text { insuficeencia renal crônica }\end{array}$ & $\begin{array}{l}\text { NasamentoLCA, } \\
\text { Coutinho EB, Silva KNG. }\end{array}$ & $\begin{array}{l}\text { Fisioterapia e } \\
\text { movimento }\end{array}$ & 2012 & Portuguese \\
\hline 19 & $\begin{array}{l}\text { Avaliaçad da qualidade de vida } \\
\text { dos pacientes submetidos a } \\
\text { hemodialise }\end{array}$ & $\begin{array}{l}\text { GrassellicSMM, Chaves } \\
\text { ECL, Simäo TP, Botelho } \\
\text { PB, Silva RR. }\end{array}$ & $\begin{array}{l}\text { Revista de } \\
\text { Enfermagem da } \\
\text { UERJ }\end{array}$ & 2012 & Portuguese \\
\hline 20 & $\begin{array}{l}\text { Differences in quality of life of } \\
\text { hemodialysis patients between } \\
\text { dialysis centers. }\end{array}$ & $\begin{array}{l}\text { Mazairac AHA, } \\
\text { Grooteman MPC, } \\
\text { Blankestijn }, \text { Penne EL, } \\
\text { Weerd NC, Hoedt } \\
\text { CH, DorpelMA, Buskens } \\
\text { E, Nube M, Wee PM, Wit } \\
\text { GA, Bots ML. }\end{array}$ & $\begin{array}{l}\text { Quality of } \\
\text { Life Research }\end{array}$ & 2012 & English \\
\hline 21 & $\begin{array}{l}\text { Influence of megestrolacetate on } \\
\text { nutrition, inflammation and } \\
\text { quality of life in dialysis patients. }\end{array}$ & $\begin{array}{l}\text { Gotebiewska } \\
\text { JE, Lichodziejewska- } \\
\text { Niemierko } \\
\text { M, Aleksandrowia- } \\
\text { Wrona E, Majkowia } \\
\text { M, Lysiak-Szzdtowska } \\
\text { W, Rutkowski. }\end{array}$ & $\begin{array}{l}\text { Tnternational } \\
\text { Urology and } \\
\text { Nephrology }\end{array}$ & 2012 & English \\
\hline 22 & $\begin{array}{l}\text { A systematic review and meta- } \\
\text { analysis of utility-based quality of } \\
\text { life in chronickidney disease } \\
\text { treatments }\end{array}$ & $\begin{array}{l}\text { WebsterCA, Howard K, } \\
\text { Hayen A, Morton RL, } \\
\text { Wyld M. }\end{array}$ & PLosmediane & 2012 & English \\
\hline 23 & $\begin{array}{l}\text { Sleep andp pain management are } \\
\text { key components of patient care in } \\
\text { ESRD }\end{array}$ & Unruh ML, Cohen LM. & $\begin{array}{l}\text { Nephrology } \\
\text { Dialysis } \\
\text { Transplantation }\end{array}$ & 2012 & English \\
\hline 24 & $\begin{array}{l}\text { Pain, sleep disturbance and } \\
\text { survival in hemodialysis patients }\end{array}$ & $\begin{array}{l}\text { Harris TJ, Nazir } \\
\text { R, Khetpal P, Peterson } \\
\text { RA, Chava P, Patel } \\
\text { SS, Kimmel PL. }\end{array}$ & $\begin{array}{l}\text { Nephrology } \\
\text { Dialysis } \\
\text { Transplantation }\end{array}$ & 2012 & English \\
\hline
\end{tabular}

Source: LILACS and MEDLINE 2011 at 2013

Regarding the type of research design of the articles evaluated, it is evident: one systematic review, twelve cross-sectional studies, five J. res.: fundam. care. online 2013.dec. 5(6): 338-347
Scientific production on quality of life in patients... descriptive studies, one propesctive study, a literature review, a multicenter, observational study a correlational study and a transeccional observational study as seen in Frame 3.

Frame 3 - Characteristics of studies according to the type of study and objectives (2011-2013)

\begin{tabular}{|c|c|c|}
\hline V & TYPE OF STUDY & OBJECTIVES \\
\hline 0 & Descriptivestudy & $\begin{array}{l}\text { Comparng the dimensions of quality of life in the stages of chronic kioney olsease } \\
\text { and the influence of sociodemographic, clinical and laboratory factors. }\end{array}$ \\
\hline 02 & $\begin{array}{l}\text { Descriptive and cross- } \\
\text { sectional study }\end{array}$ & $\begin{array}{l}\text { Determine the relattonship between depression and quality of life of patients } \\
\text { undergoing hemodialysis. }\end{array}$ \\
\hline 03 & $\begin{array}{l}\text { Observational cohort } \\
\text { study }\end{array}$ & $\begin{array}{l}\text { Determine the impact of the quality of predialysis nephrology care in health } \\
\text { quality of life at the start of dialysis. }\end{array}$ \\
\hline 04 & \begin{tabular}{|c|c|c|c|} 
Cross-sectional study \\
\end{tabular} & $\begin{array}{l}\text { Compare the mere realization of the clinical pertormance and quality of life } \\
\text { related to health in hemodialysis patients in satellite hospitals and central } \\
\text { hospitals. }\end{array}$ \\
\hline 05 & \begin{tabular}{|c|c|c|c|} 
Cross-sectional study \\
\end{tabular} & $\begin{array}{l}\text { Tdentify factors associated with quality of life related to health of elderly patients } \\
\text { on hemodialysis. }\end{array}$ \\
\hline 06 & \begin{tabular}{|c|c|c|c|} 
Cross-Sectional study \\
\end{tabular} & $\begin{array}{l}\text { Explore the intersection of sequencing the human genome, envronmental tactors } \\
\text { that provide for understanding the etiology of complex diseases, and the } \\
\text { components that constitute health related to quality of lite tor atrican-amercan } \\
\text { patients on hemodialysis. }\end{array}$ \\
\hline 07 & Descriptivestuay & $\begin{array}{l}\text { Evaluate and compare the quality of life of patients undergolng physiotherapy } \\
\text { with controls. }\end{array}$ \\
\hline 08 & $\begin{array}{l}\text { Cross-sectional and } \\
\text { descriptive study }\end{array}$ & $\begin{array}{l}\text { Compare the quality of life of hemodialysis patients without depression (A) to } \\
\text { those with some degree of depression (B). }\end{array}$ \\
\hline 09 & Descriptivestuay & $\begin{array}{l}\text { Knowng the perceptions of pattents whth chronic renal fallure about changes in } \\
\text { your routine life, from the treatment of hemodialysis, identifying the elements } \\
\text { that intluence their quality of lite. }\end{array}$ \\
\hline 10 & $\begin{array}{l}\text { Exploratory and } \\
\text { descriptive study }\end{array}$ & $\begin{array}{l}\text { Evaluate the quality of life of elderly patients with chronic renal fallure, } \\
\text { undergoing hemodialysis. }\end{array}$ \\
\hline 11 & Descriptivestuay & $\begin{array}{l}\text { Compare the level of QOL among hemodialysis patients enrolled and non-enrolled } \\
\text { on the waiting list for renal transplantation. }\end{array}$ \\
\hline 12 & $\begin{array}{l}\text { Cross-sectional and } \\
\text { descriptive study }\end{array}$ & Evaluate the lifestye of chronic renal fallure patients on hemodialysis. \\
\hline 13 & \begin{tabular}{|l|} 
Transeccional \\
correlational study
\end{tabular} & $\begin{array}{l}\text { Analyze the relationship between the varnables age, time in treatment, gender, } \\
\text { perceived family support, mental health, perceived health status and quality of } \\
\text { lite. }\end{array}$ \\
\hline 14 & \begin{tabular}{|c|} 
Cross-sectional study \\
\end{tabular} & $\begin{array}{l}\text { Evaluate the current nutritional status, quality of life and depressive symptoms, } \\
\text { and to determine possible relationships with other risk factors for bad outcomes } \\
\text { in patients in stable hemodialysis. }\end{array}$ \\
\hline 15 & \begin{tabular}{|l|l|} 
Prospective study \\
\end{tabular} & $\begin{array}{l}\text { The objective of this study was to determine the extent of } 25 \text {-hydroxymtamin D } \\
\text { (25.OH vitamin D) deficiency and associations with selffreported physical activity } \\
\text { and quality of health of lite (QOL) among participants in the Global Dialysis study } \\
\text { (CDS). }\end{array}$ \\
\hline 16 & $\begin{array}{l}\text { Cross-sectional, } \\
\text { descriptive study }\end{array}$ & $\begin{array}{l}\text { Tnvestlogate the quality of life of pattents diagnosed with chronic kidney disease on } \\
\text { hemodialysis, as with SF-36. }\end{array}$ \\
\hline 17 & Cross-5ectronalstuoy & $\begin{array}{l}\text { Find an assoclation of distance between home of the pattents and dialysis unit } \\
\text { with quality of life, depression and confrontation between renal disease (ESRD) } \\
\text { patients undergong maintenance hemodialysis. }\end{array}$ \\
\hline 18 & $\begin{array}{l}\text { Study of literature } \\
\text { review }\end{array}$ & $\begin{array}{l}\text { To revew the literature on the intluence of physical exercise in chromic renal } \\
\text { failure patients undergoing hemodialysis. }\end{array}$ \\
\hline 19 & $\begin{array}{l}\text { Eploemiological, } \\
\text { descriptive, cross. } \\
\text { sectional study }\end{array}$ & Evaluate the quality of tife of patients undergongh hemodialysis. \\
\hline 20 & \begin{tabular}{|l|} 
Cross-sectional study \\
\end{tabular} & $\begin{array}{l}\text { Evaluate the differences in HRQOLL of hemodialysis patients between dialysis } \\
\text { centers and explore what modifiable central characteristics could explain possible } \\
\text { ditterences. }\end{array}$ \\
\hline 21 & $\begin{array}{l}\text { Amulticenter } \\
\text { prospective study }\end{array}$ & $\begin{array}{l}\text { To evaluate the efficacy and satety of meegestrol acetate in undernounshed } \\
\text { dialysis patients. }\end{array}$ \\
\hline 22 & $\begin{array}{l}\text { Study of Systematic } \\
\text { review with meta. } \\
\text { analysis }\end{array}$ & $\begin{array}{l}\text { Determine useful grouped based on quality of life (the numercal value attached } \\
\text { to the strength of an individuals preference for a particular heal th outcome) by } \\
\text { modality ot treatment of CKD. }\end{array}$ \\
\hline & 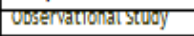 & 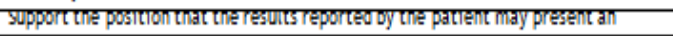 \\
\hline
\end{tabular}

Source: LILACS and MEDLINE 2011 at 2013

On the instruments used to evaluate the quality of life of patients with renal insufficient undergoing hemodialysis, it is noteworthy that 18 studies used a scale and most of these, ten studies used the Kidney Disease and Quality of Life - Short Form (SF-KDQOL) and the Short Form - 36 (SF-36) to collect the data. The instrument is considered the most complete and current to assess quality of 
Vieira ODC, Moura SRB, Pinheiro JP et al.

life in renal disease and hemodialysis, he has items of generic aspects and includes specific topics related to kidney disease.

The studies analyzed showed that several aspects influence in maintaining the quality of life of patients with renal failure undergoing hemodialysis. Here we outline the sociodemographic studies have shown that patients with a higher level of education have better physical performance than other with mid-level. Regarding the average scores on assessment of mental patients, Asian men and outperformed those without individual monthly income had lower values than those with some income. ${ }^{6}$

Regarding perceptions of the CRF patients about changes in their everyday life, from the treatment of hemodialysis, it is evident that the initial feelings were of anger and denial, but these have changed to the extent that patients were being strengthened to coping with the disease. The main difficulties reported were the restriction of food and water habits, incapacity or limitation of physical, occupational and leisure activities. It was also found that the support of family members and health professionals can help to overcome these limitations and adapting to the new lifestyle. ${ }^{7}$

Patients not awaiting transplantation evolved more frequently to die within 12 months. It was verified, therefore, that patients on dialysis who do not awaiting transplantation are at risk of experiencing poor quality of life, especially as regards the limitation due to emotional and physical aspects. It is recommended psychological support and physical rehabilitation for this group of patients. $^{8}$

The quality of life of patients is negatively affected by factors such as the dimensions of professional role, vitality, physical function, emotional function, general health and overloading of kidney disease on patients' lives; associated difficulties and challenges caused by kidney disease and its treatment. The high scores found
Scientific production on quality of life in patients... for the dimensions of patient satisfaction regarding the support received by family and friends, sex life, cognitive function, pain, sleep, social support, list of symptoms, effects of kidney disease, encouragement by dialysis staff, physical functioning , emotional well-being, social functioning and quality of social interaction, have dimensions that had high levels of scores and contributed positively to the assessment of quality of life.

The studies analyzed showed that despite the limitations that hemodialysis treatment entails, there are more important factors that motivate and encourage these patients to cope with this phase of your life, such as the will to live and stay healthy. ${ }^{9}$

The habits and customs of the people also influence their quality of life. According to the study analyzed, few patients with renal insufficiency consume alcoholic beverages, just over half practice exercise and about $12.5 \%$ smoke. The results of these studies are of great value in assessing the quality of life of these patients by helping professionals, researchers and students in order to stimulate reflections and instigate further investigations about the lives of patients with CRF. ${ }^{10}$

In elderly patients with renal failure undergoing hemodialysis, studies show that the main component affected was the physical condition of the patients. In contrast, the contact and support from family and friends influence positively the social condition. ${ }^{11}$

Increasing age, female gender and number of hospital admissions are associated directly to decreased physical condition. The presence of selfreported chronic diseases was the factor that was significantly associated with worse quality of life in all components evaluated, showing the importance of knowing the profile morbidity in elderly patients undergoing dialysis therapy to decrease the effect of these conditions on quality of life for seniors. 
Vieira ODC, Moura SRB, Pinheiro JP et al.

The treatment time was also negative influence on mental component of quality of life, suggesting a worsening of those aspects of the beginning of dialysis, which can be retrieved later. ${ }^{12}$

The perception of pain have greater importance for patients off treatment of hemodialysis than on hemodialysis, since they can be related both to the severity of disease as an adaptive response to treatment. It is important to find the cause of pain before treating it. Pain should be treated especially when they are out of hemodialysis, to improve the survival of these patients. ${ }^{13}$ Early adoption of palliative care is essential to improving the quality of life and, consequently, to increase the survival of patients with chronic renal failure. ${ }^{14}$

Malnutrition is a common clinical problem in patients undergoing hemodialysis. The use of megestrol acetate may help reverse the loss of appetite in dialysis patients, but does not reduce inflammation and improve the quality of life, and require continuous monitoring because of the high incidence of side effects. ${ }^{15}$ However, one study showed no direct association between malnutrition and quality of life of these patients. ${ }^{16}$

The practice of physical exercise, either aerobic and / or resistance, have incremental effects on functional capacity, muscle function and quality of life of renal disease undergoing hemodialysis. With this we can see that physical training has to be considered a very important therapeutic modality seen improvements in the quality of life of these patients. ${ }^{17}$

Patients on hemodialysis have a trend toward better quality of life when treated with physiotherapy, so there need to be inserted in the education of physiotherapists, most comprehensive content in the area of nephrology. ${ }^{18}$

A deficiency of vitamin D proved of great importance to patients on dialysis. One can notice a decrease in serum concentrations in patients who undergo this treatment and there is a relation
Scientific production on quality of life in patients... between this concentration with decreasing intensity of physical activity. This demonstrates once again the importance of the exercise in maintaining the quality of life of these patients. But more research is needed to determine whether the Hypovitaminosis D is causally associated with reduced physical activity. ${ }^{19}$

Hemodialysis is responsible for a series of changes in the quality of life of patients with renal disease. Among the psychological changes the major is depression. Despite being a consequence of low incidence, one should invest in social and psychological support for these patients. ${ }^{20}$ CRF depressed patients have a poor quality of life because they suffer with a chronic disease that affects its physical aspects, and to feel mentally limited. With this we realize the importance of mental health-related quality of life of patients with renal disease. ${ }^{21,22}$

Canadian study with the objective to compare the clinical performance and quality of life in patients on hemodialysis treated at satellite health unit, closer to communities and other central unit, showed that the process of care is different in these units. In satellite unit patients received fewer visits from nephrologists, but proved to have the same clinical quality and performance similar to patients seen in the central unit life, this reinforces the increasing use of satellite units to provide care closer to the patient community. ${ }^{23}$ Even if the quality of life to be a very important aspect of management for patients on hemodialysis, the study shows that there are clinically relevant differences between dialysis centers in various domains of quality of life. ${ }^{2^{4}}$

However, a study with the objective of identify an association between distance of residence of the patients and dialysis unit, with the quality of life showed no differences related to the quality of life among the three groups of patients: residents where clinical hemodialysis is installed; residents with a distance of $100 \mathrm{~km}$ and residents 
Vieira ODC, Moura SRB, Pinheiro JP et al. with a distance of over $100 \mathrm{~km}$, concluding that the distance is not a predictor of depression and neither interferes with the quality of life of patients. $^{25}$

African-American patients on hemodialysis demonstrated that environmental influences of religiosity and social support and genetic factors had a significant impact on their quality of life. ${ }^{26}$

The quality of life of patients with CRF on hemodialysis has no relationship with the time to live with the disease, nor with sex and age. However, the dimensions of mental health has higher correlation with the dimensions of quality of life. ${ }^{27}$ Patients on hemodialysis process have low quality of life due to successive situations that compromise the physical and psychological, for personal, family and social repercussions. As their quality of life, the dimensions of the vitality and mental health have higher averages and functional capacity and social aspects have lower averages. ${ }^{28}$

The hemodialysis is associated with a significant decrease in quality of life compared with patients treated with renal transplantation, this reflects the need for an economic evaluation of renal therapies useful for the adoption of a public policy on patient care chronic kidney disease on hemodialysis. ${ }^{29}$

\section{CONCLUSION}

The integrative review enabled the construction of a synthesis of scientific knowledge and to identify factors related to the quality of life of patients with renal failure undergoing hemodialysis, and those related to the physical, psychosocial, mental, and other factors, which comprehend chronological age, the presence and support of the family.

It is believed that this research will contribute significantly to the construction of new knowledge, for analyzing the various areas that
Scientific production on quality of life in patients... comprehend the quality of life of individuals may assist healthcare professionals in the instrumentalization of a healthcare practice that really contemplate the multidimensionality of care patients with renal failure undergoing hemodialysis. Furthermore, it is clearly important that more studies regarding this type of evaluation are implemented, providing opportunities to all individuals involved in this process a moment of intense reflection against daily practice of health professionals.

Although there is already a significant accumulation of knowledge regarding factors related to quality of life, it is necessary to conduct further studies both in relation to concepts regarding the construction and validation of specific scales to assess the various factors inherent in the care of patients with renal failure undergoing hemodialysis.

\section{REFERÊNCIAS}

1. Berne RM, Levy MN. Fisiologia. 5.ed. Rio de Janeiro: Elsevier; 2004.

2. Boim MA, Santos OFP, Schor N. Insuficiência renal aguda (IRA). In: AJZEN, H.; SCHOR, N. Guias de medicina ambulatorial e hospitalar. 2. ed. São Paulo: Manole; 2005.

3. Draibe SA, Aizen H. Insuficiência renal crônica (IRC). In: AJZEN, H.; SCHOR, N. Guias de medicina ambulatorial e hospitalar. 2. ed. São Paulo: Manole; 2005

4. Galvão PCA. Métodos dialíticos em Unidade de Terapia Intensiva. In: HOMSI, E. Insuficiência Renal Aguda em UTI. São Paulo: Editora Atheneu; 1998. 
Vieira ODC, Moura SRB, Pinheiro JP et al.

5. Fermi MRV. Manual de diálise para enfermagem. Rio de Janeiro (RJ): Intexto; 2003.

6. Cruz CM, Andrade C, Urrutia M, Draibe S, Martins NAL, Sesso CCR. Quality of life in patients with chronic kidney disease. Clinical Science 2011;66(6):991-995.

7. Silva SA, Silveira SR, Fernandes MFG, Lunardi LV, Backes SMV. Percepções e mudanças na qualidade de vida de pacientes submetidos à hemodiálise. Rev Bras Enferm, Brasília 2011 set-out; 64(5): 83944.

8. Santos PR. Comparação da qualidade de vida entre pacientes em hemodiálise aguardando e não aguardando transplante renal em uma região pobre do Brasil. J Bras Nefrol 2011;33(2):166-172.

9. Grasselli MSC, Chaves LCE, Simão PT, Botelho BP, Silva RR. Avaliação da qualidade de vida dos pacientes submetidos à hemodiálise. Rev Bras Clin Med. São Paulo, 2012 nov-dez;10(6):503-7.

10. Kirchner MR, Machado FR, Löbler L, Stumm FME. Análise do estilo de vida de renais crônicos em hemodiálise. 0 Mundo da saúde São Paulo: 2011;35(4):415-421.

11. Takemoto AY, Okubo P, Bedendo J, Carreira L. Avaliação da qualidade de vida em idosos submetidos ao tratamento hemodialítico. Rev J. res.: fundam. care. online 2013.dec. 5(6): 338-347
Scientific production on quality of life in patients... Gaúcha Enferm., Porto Alegre (RS) 2011 jun;32(2):256-62.

12. Braga MFS, Peixoto VS, Gomes $\mathrm{Cl}$, Acúrcio AF, Andrade GE, Cherchiglia LM. Fatores associados com a qualidade de vida relacionada à saúde de idosos em hemodiálise. Rev Saúde Pública 2011;45(6):1127-36.

13. Harris TJ, Nazir R, Khetpal P, et al. Pain, sleep disturbance and survival in hemodialysis patients. Nephrol Dial Transplant (2012) 27: 758-765.

14. Unruh LM , Cohen LM. Sleep and pain management are key components of patient care in ESRD. Nephrol Dial Transplant (2012) 27: 26182620.

15. Gotebiewska EJ, Lichodziejewska M, Aleksandrowicz E, Majkowicz M, Łysiak-Szydłowska W, Rutkowski B. Influence of megestrol acetate on nutrition, inflammation and quality of life in dialysis patients Int Urol Nephrol (2012) 44:1211 1222.

16. Barros A, da Costa PEB, Poli-de-Figueiredo EC, et al. Nutritional Status Evaluated by MultiFrequency Bioimpedance Is Not AssociatedWith Quality of Life or Depressive Symptoms in Hemodialysis Patients. Therapeutic Apheresis and Dialysis;2010: 15(1):58-65. 
17. Nascimento LCA, Coutinho ÉB, da Silva KNG. Efetividade do exercício físico na insuficiência renal crônica . Fisioter Mov. 2012 jan/mar;25(1):231-9.

18. Padulla TAS, Matta VM, Melatto T, Miranda VCR, Camargo RM. A Fisioterapia pode influenciar na qualidade de vida de indivíduos em hemodialise? Cienc Cuid Saude 2011; 10(3): 564-570.

19. Anand S, Kaysen AG, Chertow MG, et al. Vitamin D deficiency, self-reported physical activity and health-related quality of life: the Comprehensive Dialysis Study. Nephrol Dial Transplant (2011) 26: 3683-3688.

20. Ferreira CR, Silva Filho RC. A qualidade de vida dos pacientes renais crônicos em hemodiálise na região de Marília, São Paulo. J Bras Nefrol 2011;33(2):129-135.

21. Santos RP, Depression and quality of life of hemodialysis patients

living in a poor region of Brazil. Rev Bras Psiquiatr. 2011;33:332-337

22. Boini S, Frimat L, Kessler M, Briançon S, Thilly $\mathrm{N}$. Predialysis therapeutic care and health-related quality of life at dialysis onset (The pharmacoepidemiologic AVENIR study) . Health and Quality of Life Outcomes 2011; 9:7

J. res.: fundam. care. online 2013.dec. 5(6): 338-347
23. Diamant MJ, Young J, Gallo k, Xi W, Suri SR, Garg XA, Moist ML. Hemodialysis in a Satellite Unit: Clinical Performance Target Attainment and Health-Related Quality of Life. Clin J Am Soc Nephrol 2011; 6: 1692-1699.

24. Mazairac AHA, et al. Differences in quality of life of hemodialysis patients

between dialysis centers. Qual Life Res (2012) 21:299-307.

25. Santos PR, Arcanjo NPF. Distance between residence and the dialysis unitdoes not impact selfperceived outcomes in hemodialysis patients. BMC Research Notes 2012, 5:458.

26. Thomas JC, School of Social Work, Morgan State University, Baltimore, Maryland, USA. The Confluence of Human Genomics, Environment, and Determinants of Health-Related Quality of Life among African American Hemodialysis Patients. Downloaded by [187.41.181.175] at 21:52 14 November 2013.

27. Urzúa A, Pavlov R, Cortés R, Pino V. Factores Psicosociales Relacionados con la Calidad de Vida en Salud en Pacientes Hemodializados. Terapia psicológica 2011, Vol. 29, №1, 135-140. 
Vieira ODC, Moura SRB, Pinheiro JP et al.

28 Farias, QFMC, Ramos PV, Lira CBLA. Qualidade de vida dos pacientes submetidos a hemodiálise. Rev. enferm. UERJ, Rio de Janeiro, 2011 out/dez; 19(4):577-82.

29. Webster CA, Howard K, Hayen A, Morton LR, Wyld M. A Systematic Review and Meta-Analysis of Utility-Based Quality of Life in Chronic Kidney Disease Treatments.

Received on: 04/02/2013

Required for review: no

Approved on: 25/10/2013

Published on: 27/12/2013
Scientific production on quality of life in patients... 